\title{
MENINJAU KEMBALI PENYELESAIAN SENGKETA KONSUMEN DI INDONESIA : ASPEK KELEMBAGAAN DALAM RANGKATERCAPAINYA KEPASTIAN HUKUM
}

\author{
Anita Afriana; Sudaryat; Rai Mantili; Ema Rahmawati \\ Fakultas Hukum Universitas Padjadjaran \\ Email:anita.afriana@unpad.ac.id
}

\begin{abstract}
Due to the upward trends of business transaction both in conventional and online basis, it is deemed necessary to find an effective ways to settle disputes in the event of a losses to the consumers. In general, consumer disputesinvolve small amount of lossand complaint filed by the consumers for material compensation. In Indonesia, consumer disputeresolutionis carried out not only by the Consumer Dispute SettlementBody (BPSK)but also throughthecourts. Recently,there are manynewly-established consumer disputesettlement institutions.A quick, simple, and low-cost consumer dispute mechanism isneeded to cope with Indonesian economic growth by accelerating the time of a dispute settlement (time efficiency). The purpose of this research is find out how consumer disputes are resolved in Indonesia and legal discource in the frame work oft he consumer's disputere solution which have lawcertainty.it can be concluded that the plurality of consumer disputesettlement in Indonesia has ledtoconvoluted mechanisms and procedures in settling disputes. Dispute settlement through Badan Penyelesaian Sengketa Konsumen/Consumers Dispute Settlement Agency (BPSK) is not final and binding. Through this article, it is recommended to utilise Small Claims Procedures that combines informal and formal mechanisms in order to achieve legal certainty in the settlement of consumer disputes in Indonesia.
\end{abstract}

Keywords : consumerdispute, institution, small claims prosedures

\section{PENDAHULUAN}

Badan hukum dan manusia sebagai subjek hukum.Sudah merupakan kodratnya bahwa manusia sebagai mahkluk sosial memerlukan interaksi sosial satu dengan yang lain. Adanya kepentingan yang berbeda dalam interaksi tersebut dapat menimbulkan konflik kepentingan. Konflik yang tidak dapat diselesaikan akan berkembang menjadi sengketa. Sengketa dapat diselesaikan melalui mekanisme penyelesaian sengketa.

Mengamati kegiatan yang jumlah transaksi semakin meluas, tidak mungkin dihindari terjadinya sengketa (dispute/difference) antar pihak yang terlibat. Setiap jenis sengketa yang terjadi selalu menuntut pemecahan dan penyelesaian yang cepat. Makin banyak dan luas kegiatan perdagangan, frekuensi terjadi sengketa makin tinggi, hal ini berarti sangat mungkin makin banyak sengketa yang harus diselesaikan

Cara penyelesaian sengketa jika dilihat dari sudut pandang prosesnya (mekanisme) dapat dilakukan secara konvensional yaitu diselesaikan melalui pengadilan (litigasi) dengan menggunakan pendekatan hukum atau mekanisme alternatif melalui cara damai atau perundingan disebut juga sebagai mekanisme penyelesaian sengketa alternatif (non litigasi) dengan tidak menggunakan pendekatan hukum formal.

Berdasarkan sistem kekuasaan kehakiman di Indonesia, kewenangan memeriksa dan memutus perkara menjadi kewenangan hakim. Tugas hakim ( pengadilan) adalah menerima, memeriksa, dan memutus setiap perkara-perkara 
MENINJAU KEMBALI PENYELESAIAN SENGKETA KONSUMEN DI INDONESIA....(Anita Afriana; Sudaryat; Rai Mantili; Ema Rahmawati, 74-83)

perdata maupun pidana yang diajukan kepadanya ${ }^{1}$. Bila dilihat dari sudut pandang pembuat keputusan dapat dilakukan secara ajudikatif yaitu mekanisme penyelesaian yang ditandai dengan kewenangan pengambilan keputusan yang dilakukan oleh pihak ketiga dalam sengketa diantara para pihak dan secara konsensual/kompromi melalui quasiadjudikatif yaitu merupakan kombinasi antara unsur konsensual dan adjudikatif.Perbedaan prinsip antara penyelesaian melalui pengadilan dan di luar pengadilan adalah mengenai dapat tidaknya dicapai kepastian hukum, yang merupakan salah satu tujuan hukum melalui putusan pengadilan selain keadilan dan kemanfaatan.

Seiring waktu dan kebutuhan masyarakat, penyelesaian sengketa perdata di luar pengadilan mengalami perkembangan. Berbagai bidang memiliki lembaga penyelesaian sendiri di luar pengadilan yang diatur dalam peraturan perundangundangan sendiri. Salah satu contoh dari sengketa perdata adalah sengketa konsumen. Sengketa konsumen dapat dengan mudah terjadi mengingat manusia dalam aktivitas kesehariannya dengan mengkonsumsi barang dan atau jasa baik dalam skala besar maupun kecil.

Globalisasi adalah suatu keniscayaan yang tidak mungkin dihindari oleh bangsa dan negara manapun karena arus informasi yang cepat dan menjangkau wilayah yang sangat luas serta tanpa batas. ${ }^{2}$ Perkembangan tersebut diciptakan seiring dengan kebutuhan manusia, yaitu untuk memudahkan hidup dari yang sebelumnya ${ }^{3}$ dan teknologi informasi telah mengubah cara-cara bertransaksi dan membuka peluang-peluang baru dalam transaksi bisnis. ${ }^{4}$ Transaksi bisnis melibatkan para pihak yang dapat dikualifikasikan sebagai konsumen dan pelaku usaha.

Pengertian sengketa konsumen tidak dijelaskan dalam Undang-Undang No. 8 Tahun 1999 Tentang Perlindungan Konsumen (UUPK), tapi ditemukan dalam Keputusan Menteri Perindustrian dan Perdagangan RINo. 350/MPP/ Kep/12/2001 Tentang Pelaksanaan Tugas dan Wewenang Badan Penyelesaian Sengketa Konsumen, yang menyebutkan bahwa sengketa konsumen yang menuntut ganti rugi atas kerusakan, pencemaran dan/atau yang menderita kerugian akibat mengkonsumsi barang dan/atau memanfaatkan jasa.Az. Nasution ${ }^{55}$ Az. Nasution, 2011, Hukum Perlindungan Konsumen Suatu Pengantar, Diadit Media 2011, hlm 229 mengemukakan bahwa sengketa konsumen adalah sengketa antara konsumen dengan pelaku usaha (publik atau privat) tentang produk konsumen, barang dan/atau jasa konsumen tertentu. Untuk menentukan apakah suatu sengketa merupakan suatu sengketa konsumen atau bukan, perlu kiranya diperhatikan apakah pihak konsumen yang bersengketa tersebut merupakan konsumen sebagaimana yang dimaksud konsumen dalam Undang-Undang No. 8 Tahun 1999 Tentang Perlindungan Konsumen ( selanjutnya disebut UUPK) serta produk yang disengketakan tersebut adalah sebagai produk konsumen. Berdasarkan teori yang ada, penyelesaian sengketa konsumen dapat dilakukan secara damai, melalui pengadilan, maupun melalui Badan Penyelesaian Sengketa Konsumen (BPSK)

Berdasarkan data yang ada, sangat jarang sengketa konsumen diselesaikan melalui pengadilan. Adapun yang menjadi alasannya karena sengketa konsumen bernilai kerugian yang relatif sedikit, murah, dan merupakan sengketa sederhana. Bila diselesaikan melalui pengadilan dengan melalui tahapan beracara mulai dari gugatan hingga putusan dinilai tidak cukup efektif baik dari segi waktu maupun biaya yang ditimbulkan. Pada perkembangannya bermunculan lembaga alternatif penyelesaian sengketa di luar pengadilan selain BPSK, diberbagai lini terdapat semacam lembaga penyelesaian konsumen antara lain dalam bidang perbankan ( LAPSPI), pasar modal, maupun komiditi berjangka. Adapun latar belakang pembentukan Lembaga Alternatif Penyelesaian Sengketa (LAPS) di OJK adalah karena seringnya tidak tercapai kesepakatan antara Konsumen dengan Lembaga Jasa Keuangan

Bagi para pihak yang telah memilih penyelesaian sengketa konsumen melalui di luar pengadilan, konsumen tidak dapat mengajukan gugatan kepada pelaku usaha melalui pengadilan secara bersamaan. Gugatan melalui pengadilan 
hanya dapat dilakukan apabila penyelesaian sengketa konsumen diluar pengadilan yang telah ditempuh dinyatakan tidak berhasil oleh salah satu pihak yang bersengketa.

Sesungguhnya penyelesaian sengketa konsumen bernilai kerugian kecil. Diberbagai negara digunakan mekanisme Small Claims Prosedures untuk menyelesakan sengketa konsumen yang menjembatani antara penyelesaian sengketa melalui jalur non litigasi dengan litigasitidak saja untuk gugatan konsumen, tetapi juga dalam perkembangannya berwenang untuk menyelesaian sengketa perdata yang lebih luas ${ }^{6}$. Di Indonesia selanjutnya Small Claims Prosedures ini diadopsi konsepnya dalam gugatan sederhana, yang antara lain digunakan untuk menyelesaikan sengketa konsumen di bawah nilai 500 juta Rupiah.

Tulisan ini selanjutnya akan membahas tentang eksistensi keberagamaan lembaga penyelesaian sengketa konsumen di Indonesia dan kelembagaan penyelesaian sengketa konsumen yang dapat dintegrasikan sebagai small claims procedures yang dapat diselesaikan dengan menggunakan gugatan sederhana di pengadilan.

\section{METODE PENELITIAN}

Artikel ini merupakan bagian kecil dari Penelitian Dasar Perguruan Tinggi yang sedang dilakukan ( Tahun 2018 dan 2019), dan sebagian hasilnya disosialisasikan pula dalam kegiatan Pengabdian Kepada Masyarakat di Desa Mangkurayat, Kecamatan Cilawu Kabupaten Garut, Jawa Barat untuk memperkenalkan macam macam lembaga penyelesaian konsumen sehingga diharapkan dapat meningkatkan pengetahuan masyarakat.

Penelitian dilakukan secara yuridis normatif yang mengedepankan data sekunder yang selanjutnya dipaparkan secara deskriptif analitis dan disimpulkan secara yuridis kualitatif. Sebagian hasil dari penelitian yang juga dituangkan dalam artikel ini adalah pengaturan di beberapa negara tentang Small Claims Prosedures untuk menyelesaikan sengketa konsumen.

\section{PEMBAHASAN}

Eksistensi Keberagamaan Lembaga Penyelesaian Sengketa Konsumen Di Indonesia

Penyelesaian sengketakonsumen menurut Pasal 45 UU No. 8 Tahun 1998 Tentang UndangUndang Perlindungan Konsumen ( UUPK) dapat dilakukan melalui pengadilan maupun di luar pengadilan. Penyelesaian sengketa konsumen melalui pengadilan akan masuk dalam ranah sengketa perdata yang dilakukan secara berjenjang yakni melalui peradilan yang berada di lingkungan peradilan umum. Penyelesaian sengketa konsumen di luar pengadilan maupun penyelesaian sengketa konsumen di pengadilan ditempuh berdasarkan pilihan sukarela para pihak yang bersengketa.

Pilihan sukarela para pihak menunjukkan bahwa terhadap penyelesaian sengketa yang terjadi antara konsumen dan pelaku pada dasarnya merupakan komproni para pihak yang bersengketa, namun apabila tidak terdapat kesepakatan antara konsumen dan pelaku usaha mengenai penentuan dimana akan diselesaikannya sengketa konsumen, maka pilihan mana yang akan ditempuh adalah merupakan pilihan kepada konsumen untuk melakukan gugatan kepada pengadilan

Bagi para pihak yang telah memilih penyelesaian sengketa konsumen melalui di luar pengadilan, konsumen tidak dapat mengajukan gugatan kepada pelaku usaha melalui pengadilan secara bersamaan. Gugatan melalui pengadilan hanya dapat dilakukan apabila penyelesaian sengketa konsumen diluar pengadilan yang telah ditempuh dinyatakan tidak berhasil oleh salah satu pihak yang bersengketa.

Penyelesaian sengketa konsumen melalui BPSK tidak disebutkan secara langsung dalam UUPK. UUPK hanya menyebutkan bahwa konsumen dapat menggugat pelaku usaha melalui lembaga yang bertugas menyelesaikan sengketa antara konsumen dan pelaku usaha. Namun, ketidakjelasan ini terjawab berdasarkan ketentuan Pasal 52 huruf a UUPK, bahwa lembaga yang dimaksud adalah BPSK. Gugatan yang diajukan konsumen kepada pelaku usaha melalui BPSK 
salah satu bentuk penyelesaian sengketa konsumen diluar pengadilan. Secara filosofis dimaksudkan untuk menangani dan menyelesaikan sengketa antara konsumen dan pelaku usaha, yang pada awalnya BPSK ini menyelesaikan sengketa konsumen yang berskala kecil dan sederhana, artinya pemerintah membentuk BPSK dalam rangka pemerataan keadilan, maksudnya karena sengketa konsumen umumnya bernominal kecil, sehingga apabila diajukan ke Pengadilan Negeri tidak sebanding antara biaya perkara dengan ganti kerugian yang akan diterima konsumen. Oleh karena itu, BPSK dalam menyelesaikan sengketa konsumen dilakukan secara cepat, maksudnya dalam jangka waktu 21 hari sengketa itu harus diputus, secara mudah maksudnya proses administrasi dan proses pengambilan keputusan sangat sederhana dan dapat dilakukan oleh para pihak, dan murah karena biaya persidangan yang dibebankan pada konsumen sangat ringan dan terjangkau oleh konsumen.

Prinsip penyelesaian sengketa secara cepat, mudah dan murah pada umumnya telah diterapkan dan dilaksanakan, di beberapa BPSK yang mana persidangan sengketa konsumen tidak dipungut biaya dan diselesaikan dalam waktu yang tepat.Pembentukan BPSK dimaksudkan juga untuk membantu beban kerja PN. Oleh karenanya, BPSK hanya menangani perkara perdata saja yang umumnya menuntut ganti kerugian atas kerugian yang dialami langsung oleh konsumen atas kesalahan dan atau kelalaian pelaku usaha. BPSK dalam menyelesaikan sengketa konsumen hanya untuk menetapkan bentuk dan besaran ganti rugi serta menentukan tindakan tertentu guna menjamin bahwa tidak akan terulang kembali kerugian yang diderita konsumen. BPSK hanya berwenang menjatuhkan ganti kerugian dari pelaku usaha kepada konsumen secara materiil, bukan ganti kerugian immateril.BPSK merupakan lembaga yang menyelesaikan sengketa konsumen dan memiliki kewajiban untuk memutus sengketa antara konsumen dan pelaku usaha dalam menetapkan kerugiannya. Oleh karena itu kedudukan BPSK harus netral dan tidak berpihak. Kewajiban untuk membayar ganti rugi sebagaimana yang diputuskan oleh BPSK diberikan untuk kepentingan konsumen, maka seharusnya yang dapat mengajukan eksekusi terhadap putusan BPSK adalah konsumen bukan BPSK.

BPSK diberikan wewenang oleh UUPK untuk memutus dan menetapkan ada atau tidak kerugian dipihak konsumen, memberitahukan putusan kepada pelaku usaha yang melakukan pelanggaran terhadap perlindungan konsumen, serta menjatuhkan sanksi administratif kepada pelaku usaha yang melanggar ketentuan UUPK. Dalam menangani penyelesaian sengketa konsumen yang berwenang untuk menetapkan siapa yang menjadi majelis dalam menyelesaikan sengketa konsumen adalah ketua BPSK. Berdasarkan UUPK pada Pasal 54 ayat (3) dinyatakan bahwa putusan BPSK bersifat final dan namun pada Pasal yang selanjutnya, yakni Pasal 56 ayat (2) dinyatakan bahwa para pihak dapat mengajukan keberatan ke Pengadilan terhadap putusan yang dijatuhkan oleh BPSK. Isi daripada kedua Pasal tesebut menimbulkan penafsiran yang berbeda, khususnya pada kekuatan hukum putusan BPSK. BPSK merupakan salah satu lembaga quasi yudisial.

Lembaga quasi yudisial atau semi pengadilan merupakan lembaga-lembaga yang memiliki sifat mengadili namun tidak dapat dikatakan sebagai pengadilan. Berdasarkan Undang-Undang, lembaga tersebut diberikan wewenang untuk memeriksa, menyelesaikan dan memutuskan suatu perselisihan ataupun perkara pelanggaran hukum serta perkara pelanggaran etika tertentu dengan keputusan yang bersifat final dan mengikat sebagamana putusan pengadilan yang bersifat "inkracht" pada umumnya. Namun dalam menyelesaikan sengketa BPSK tidak memiliki kepastian hukum karena putusan BPSK yang tidak memiliki kekuatan eksekutorial yang berdampak pada hilangnya perlidungan hak-hak konsumen?

Dalam praktik, pelaksanaan putusan BPSK terkadang menjadi persoalan pada saat pelaku usaha tidak mengajukan keberatan, tetapi tidak juga melaksanakan putusan BPSK. 
Demikian pula eksekusi putusan BPSK menggunakan dasar yang diatur dalam $\mathrm{HIR} / \mathrm{RBg}$. BPSK tidak bertindak atas nama konsumen. BPSK justru bertindak sebagai arbiter untuk menyelesaikan sengketa konsumen dan pelaku usaha. Dengan adanya upaya keberatan terhadap putusan BPSK di Pengadilan Negeri hingga ke Mahkamah Agung mengakibatkan hak konsumen tidak terpenuhi dengan pasti sehingga konsumen tertunda untuk mendapatkan ganti rugi dikarenakan harus menunggu selesainya proses upaya hukum. Apabila hal tersebut dikaitkan dengan Undang-Undang Nomor 30 Tahun 1999 tentang Arbitrase dan Alternatif Penyelesaian Sengketa, maka tampak ada ketidakkonsistenan, karena dalam putusannya yang bersifat final dan mengikat, tidak ada upaya hukum banding dan kasasi.17 Pengajuan upaya keberatan tidak hanya terdapat dalam UUPK namun secara khusus diatur dalam Peraturan mengenai pengajuan keberatan atas putusan BPSK dijelaskan dalam Peraturan Mahkamah Agung Nomor 1 Tahun 2006 tentang Tata Cara Pengajuan Keberatan Terhadap Putusan BPSK. Pasal 1 ayat (3) Perma Nomor 1 Tahun 2006 memberikan pengertian bahwa keberatan adalah upaya bagi pelaku usaha dan konsumen yang tidak dapat menerima putusan BPSK. Keberatan hanya dapat diajukan terhadap putusan arbitrase yang dikeluarkan oleh BPSK. Dalam Pasal 6 Perma Nomor 1 Tahun 2006 membahas mengenai tata acara pemeriksaan keberatan. Pemeriksaan keberatan hanya dapat dilakukan atas dasar putusan BPSK dan berkas 17 Isis Ikhwansyah, Hukum Persaingan Usaha Dalam Implementasi Dan Praktik, Unpad Pres, Bandung: 2010, hlm.68. 32 Jurnal Bina Mulia Hukum Volume 4, Nomor 1, September 2019 perkara. Pasal 70 Undang-Undang Nomor 30 Tahun 1999 tentang Arbitrase dan Alternatif Penyelesaian Sengketa mengatur tentang unsur-unsur terhadap putusan arbitase yang dapat diajukan permohonan pembatalan yaitu: Surat atau dokumen yang diajukan dalam pemeriksaan, setelah putusan dijatuhkan, diakui palsu atau dinyatakan palsu. Kendala yang dihadapi oleh Badan Penyelesaian Sengketa Konsumen dalam menyelesaikan sengketa yaitu: Pertamakendala kelembagaan yaitu terlalu kompleksnya tugas Badan Penyelesaian Sengketa Konsumen meliputi tugas yang berkaitan dengan penyelesaian sengketa dan tugas diluar penyelesaian sengketa (upanya pembinaan dan pengawasan). Kedua kendala pendanaan, belum adanya aturan yang secara tegas dan rinci mengatur mengenai alokasi yang rasional yang seharusnya di alokasikan untuk Badan Penyelesaian Sengketa Konsumen. Ketiga kendala sumber daya manusia Badan Penyelesaian Sengketa Konsumen, masih kurangnya sumber daya manusia BPSK yang mempunyai keahlian dalam menyelesaikan sengketa konsumen. Keempat rendahnya kesadaran hukum perlindungan konsumen, hal ini disebabkan minimnya informasi kepada masyarakat menyangkut hak-hak nya sebagai konsumen untuk dapat menuntut haknya melalui penyelesaian sengketa di Badan Penyelesaian Sengketa Konsumen.18 Perlu dilakukan optimalisasi Badan Penyelesaian Sengketa Konsumen di seluruh indonesia, agar penyelesaian sengketa di BPSK bisa lebih efektif. PENUTUP Badan Penyelesaian Sengketa Konsumen (BPSK) adalah badan yang bertugas menangani ${ }^{8}$

Pada perkembangannya terdapat pula Lembaga Alternatif PenyelesaianSengketa (LAPS) yang ditujukan khusus pada konsumen di sektor jasa keuangan yang memiliki karakteristik permasalahan-permasalahan di sektor jasa keuangan. LAPS Sektor Jasa Keuangan yang telah terbentuk dan dimuat dalam Daftar Lembaga Alternatif Penyelesaian Sengketa di Otoritas Jasa Keuangan saat ini.

Pasal 31 ayat (1) POJK Nomor 1/ POJK.07/2013 tentang Perlindungan Konsumen Sektor Jasa Keuangan menyebutkan bahwa Pelaku Usaha Jasa Keuangan dilarang dengan cara apapun, memberikan data dan/atau informasi mengenai Konsumen nya kepada pihak ketiga. Keberadaan Lembaga Alternatif Penyelesaian Sengketa (LAPS) sektor jasa keuangan telah membawa kepastian hukum penyelesaian sengketa konsumen di sektor jasa keuangan. Namun keberadaan LAPS sektor jasa keuangan juga menimbulkanke_dakjelasan mengenai kedudukan 
dan pilihan forumpenyelesaian sengketa konsumen terkait keberadaan Badan Penyelesaian Sengketa Konsumen (BPSK) dalam kerangka hukum perlindungan konsumen di Indonesia9. Dalam perkembangannya selain BPSK dan penyelesaian melalui LAPS di OJK, terdapat lembaga penyelesaian konsumen di BAKTI khusus untuk komoditi berjangka.

Berdasarkan uraian di atas, hasil penelitian menunjukkan bahwa terjadi pluralisme dalam bidang penyelesaian sengketa konsumen berkaitan dengan kelembagaan dan aturan yang ada. Masingmasing lembaga memiliki kewenangan bertindak berdasar pada aturan yang dibuat oleh instansi/departemen. Adanya pluralisme tersebut menyebabkan ketidaksederhanaan dalam penyelesaian sengketa demikian pula dapat menimbulkankendalabagi tercapainya kepastian hukum dalam upaya penegakan hukum, sebagai contoh untuk konsumen yang dirugikan dalam kegiatan lalu lintas jasa keuangan tidak ada suatu larangan apabila memilih untuk menyelesaikan sengketa melalui BPSK daripada membawa sengketa untuk diselesaikan melalui LAPSPI. Dengan adanya pluralisme peraturan berarti bahwa terhadap hal yang sama ada dua atau lebih peraturan berbeda, sehingga menyebabkan adanya ketidakpastian hukum dalam menerapkan aturan tersebut ${ }^{10}$. Hal ini sejalan dengan pendapat Erman Rajagukguk bahwa kondisi pluralisme hukum yang ada di Indonesia menyebabkan banyak permasalahan, kendala yang terberat adalah dalam mewujudkan kepastian hukum. ${ }^{11}$

\section{Sengketa Konsumen dan Small Claims Procedures}

Konstruksi hubungan hukum antara pelaku usaha dengan konsumen semestinya setara (equal), namun secara de facto maupun dejure konsumen berada dalam posisi yang lemah. Beberapa faktor yang menyebabkan lemahnya posisi konsumen, antara lain adalah faktor ketidaktahuan konsumen atau kurangnya informasi dan keadaan daya tawar konsumen, serta posisi konsumen yang seolah-olah berada satu langkah di belakang pelaku usaha. Di sisi lain, pelaku usaha tampak lebih well in formed dan powerful di bandingkan konsumennya. ${ }^{2}$ Dalam kegiatan bisnis yang sehatter dapat keseimbangan perlindungan hukum antara konsumen dengan pelaku usaha.

Hubungan hukum dapat dituangkan dalam bentuk perjanjian tertulis di antara kedua belah pihak sehingga substansi perjanjian tersebut idealnya dilakukan berdasarkan kesepakatan terkait hak dan kewajiban secara bertimbal balik. Namun, dalam praktek sering terjadi perjanjian tersebut klausulanya ditentukan secara sepihak agar lebih cepat dan praktis, sehingga ada kemungkinan substansi dari perjanjian tersebut dapat merugikan salah satu pihak. Dalam tataran teori, perjanjian yang demikian dikenal dengan perjanjian standar atau kontrak baku, yaitu perjanjian yang klausulanya ditentukan secara sepihak oleh pihak yang menyerahkan barang atau jasa. Di sisi lain, hukum perjanjian memiliki beberapa asas untuk mengatur hubungan hukum yang perlu ditaati oleh subyek yang melakukan perjanjian sehingga tercipta kepastian dan keadilan.

Dewasa ini seiring dengan berkembangnya perniagaan berpengaruh terhadap kompleksitas kerugian konsumen. Konsumen dapat dirugikan dalam bnetuk transaksi apapun baik dalam hubungan hukum yang bersifat langsung, maupun melalui online. Sesungguhnya dengan nilai kerugian yang relatif terbatas, sengketa konsumen diselesaikan dengan prosedure yang sederhana / smallclaimsprocedures.

Para pihak dapat memilih cara penyelesaian sengketa mana akan digunakan dalam menyelesaikan permasalahannya. Apakah menggunakan proses pengadilan atau proses luar pengadilan. Apabila para pihak telah sepakat dalam memilih proses penyelesaian sengketa yang akan digunakan, maka terhadap pilihan tersebut para pihak wajib mengikutinya. Apabila para pihak sepakat memilih penyelesaian sengketa melalui BPSK, maka majelis BPSK wajib menangani dan menyelesaikan sengketa konsumen sesuai dengan pilihan para pihak.

Di samping lembaga Pengadilan, dewasa ini juga banyak tumbuh dan berkembang adanya lembagalembaga yang meskipun tidak disebut 
eksplisit sebagai pengadilan, tetapi memiliki kewenangan dan makanisme kerja yang juga bersifat mengadili. Berdasarkan ketentuan Undang-Undang, lembaga-lembaga demikian ini diberikan kewenangan untuk memeriksa dan memutus sesuatu perselisihan ataupun perkara pelanggaran hukum, dan bahkan perkara pelanggaran etika tertentu dengan keputusan yang bersifat final dan mengikat (final andbinding) sebagaimana putusan pengadilan yang bersifat “inkracht” pada umumnya. Semua ini dimaksudkan untuk memberikan keadilan bagi para pihak yang dirugikan oleh sesuatu sistem pengambilan keputusan yang mengatas-namakan kekuasaan negara.4 Karena itu, dapat dikatakan bahwa lembaga-lembaga yang bersifat mengadili tetapi tidak disebut sebagai pengadilan itu merupakan lembaga kusi pengadilan atau semi pengadilan. Beberapa di antaranya berbentuk komisi-komisi negara, tetapi ada pula yang menggunakan istilah badan atau pun dewan. Lembaga-lembaga ini, di samping bersifat mengadili, seringkalijuga memiliki fungsi-fungsi yang bersifat campuran dengan fungsi regulasi dan/ataupun fungsi administrasi. Fungsi regulasi dapat dikaitkan dengan fungsi legislatif menurut doktrin 'trias-politicaMostesquieu', sedangkan fungsi administrasi identik dengan fungsi eksekutif. Karena itu, komisikomisi negara atau lembaga-lembaga yang memiliki kewenangan mengadili ini dapat dikatakan merupakan lembaga yang memiliki fungsi campuran.

Di negara lain seperti Singapura, Australia, Malaysia,maupun Belanda, sengketa konsumen juga dapat diselesaikan baik secara litigasi maupun non litigasi. Di Singapura misalnya, ketika diselesaikan melalui Pengadilan, maka prosedure yang digunakan berupa penyelesaian secara cepat dengan mekanisme gugatan kecil ( Small Claims Court). Penyelesaian melalui pengadilan pun untuk sengketa konsumen dilakukan dengan prosedur smallclaimscourt dengan nilai gugatan tidak melebihi 5,000,00 Ringgit Malaysia. TCCM merupakan lembaga independent yang tidak memiliki kompetensi menyelesaikan sengketa konsumen berkaitan dengan korban kematian, luka, berkaitan dengan tanah perumahan serta apartement, sengketa merek, waralaba, dan perkara hak intelektual lainnya, karena dalam hal demikian menjadi kewenangan dari lembaga lainnya yang telah ditentukan oleh undangundang ${ }^{13}$.

Badan Penyelesaian Sengketa Konsumen diadopsi dari model SmallClaim Tribunal (SCT) yang telah berjalan efektif di negara-negara maju, namun BPSK temyata tidak serupa dengan SCT. Sebagaimana diketahui SCT berasal dari negaranegara yang bertradisi atau menganut sistem hukum Common Law atau Anglo Saxon memiliki cara berhukum yang sangat dinamis dimana Yurisprudensi menjadi hal utama dalam penegakan hukum. Sedangkan Indonesia menganut tradisi atau sistem hukum Civil Law atau Eropa Kontinental yang bersumber dari hukum tertulis (peraturan perundang-undangan). BPSK didesain dengan memadukan kedua sistem hukum tersebut, dimana model SCT diadaptasikan dengan model pengadilan dan model ADR (Alternative Dispute Resolution) khas Indonesia.

Pembentukan suatu forum penyelesaian sengketa khususnya sengketa konsumen melalui pengadilan secara efisien, cepat, dan biayaringanbagiperkara yang nilai gugatannya kecil khususnya sengketa bisnis, merupakan hal yang krusial di Indonesia. Salah satu bentuk reformasi peradilan dalam penyelesaian sengketa perdata adalah reformasi sistem peradilan perdata dengan memberikan kewenangan pada pengadilan negeri untuk menyelesaikan perkara secara cepat yang didasarkan pada besar kecilnya nilai objek sengketa yaitu melalui PerMANo. 4 Tahun 2019 Tentang Penyelesaian Gugatan Sederhana.

Berdasarkan hasil penelitian yang membedakan antara penyelesaian sengketa di malaysia dan Singapura sebagaimana disebutkan di atas bahwa di negara lain pun penyelesaian sengketa konsumen dilakukan melalui lembaga non litigasi dan litigasi melalui mekanisme Small Claim Procedures, sementara di Indonesia tidaklah demikian.

Pengaturan gugatan sederhana didasarkan pada konsep SCC yang diadopsi dari sistem peradilan di Amerika Serikat dan Australia. 
MENINJAU KEMBALI PENYELESAIAN SENGKETA KONSUMEN DI INDONESIA....(Anita Afriana; Sudaryat; Rai Mantili; Ema Rahmawati, 74-83)

Konsep peradilan model ini merupakan pengadilan kecil yang merupakan struktur pengadilan terpisah yang masuk yurisdiksi pengadilan tingkat pertama. Hukum acara yang digunakan dengan acara cepat dengan proses pembuktian yang sederhana. Mengutip pernyataan Erman Rajagukguk yang menyatakan bahwa globalisasi hukum akan menyebabkan peraturan negara-negara berkembang mengenai investasi, perdagangan dan jasa bidang ekonomi mendekati negara-negara maju ( convergency) ${ }^{14}$, oleh karenanya dewasa ini tidak saja dalam bidang hukum ekonomi tetapi juga hukum acara terdapat pengaruh yang cukup kuat dari sistem hukum commonlaw

Adanya prosedur gugatan sederhana ditujukan untuk menyongsong era perdagangan bebas ASEAN mulai 2015 yang diperkirakan banyak terjadi konflik perkara-perkara niaga/ bisnis dalam skala kecil yang berujung ke pengadilan. PerMA ini terbit untuk mempercepat proses penyelesaian perkara sesuai asas peradilan sederhana, cepat, biaya ringan, mengingat selama ini masyarakat pencari keadilan masih mengeluhkan lamanya proses berperkara di pengadilan. Karena itu, diperlukan percepatan proses persidangan dengan sistem peradilan SCC yang sangat penting bagi dunia perdagangan dan investor yang klaim gugatannya kecil agar proses pemeriksaan diselesaikan secara cepat.

Paradigma proses berperkara ke pengadilan yang harus menempuh prosedur beracara yang panjang dan memerlukan waktu yang lama, upaya hukum yang berjenjang haruslah diubah sejalan dengan pembaharuan hukum. Dengan kata lain, proyeksi pengadilan selain menegakkan hukum juga membantu pencari keadilan mengatasi segala hambatan dan rintangan agar tercapainya peradilan yang sederhana, cepat, dan biaya ringan.

Dengan nilai gugatan maksimal 500 juta, perkara diselesaikan dengan hakim tunggal, pembuktian sederhana, mengenal pemeriksaan pendahuluan, dan mengupayakan perdamaian sepanjang proses pemeriksaan perkara, maka perkara sederhana cukup diselesaikan dalam waktu maksimal 25 hari. Sesungguhnya tata cara
( prosedur) yang dipergunakan untuk menyelesaikan gugatan sederhana di Indonesia mengadopsi SCP. Adapun yang menjadi tujuan SCP adalah untuk menyelesaikan perkara gugatan dengan waktu yang cepat, biaya murah dan menghindari proses berperkara yang kompleks dan formal ${ }^{15}$. Melalui SCP dimaksudkan untuk memberikan solusi yang cepat dan ekonomis untuk menyelesaikan sengketa, khususnya bagi sengketa dengan nilai kerugian yang tidak terlalu besar sehingga tidak membutuhkan biaya yang mahal.

Dalam era globalisasi, yang mana pertumbuhan iklim ekonomi dan bisnis meningkat tajam, sudah saatnya Indonesia memberikan berbagai kemudahan bagi para pihak untuk melakukan usahanya, yang tidak saja berkaitan dengan sektor permodalan, tetapi juga terwujudnya keadilan (access tojustice) bagi para pihak yang berperkara serta kepastian hukum terkait dengan penyelesaian sengketa salah satunya bagi konsumen ${ }^{16}$.

Sebagaimana yang diatur dalam Peraturan Mahkamah Agung Tentang Penyelesaian Gugatan Sederhana, kewajiban bagi hakim untuk berperan aktif dalam bentuk memberikan penjelasan mengenai acara gugatan sederhana secara berimbang kepada para pihak; mengupayakan penyelesaian perkara secara damai termasuk menyarankan kepada para pihak untuk melakukan perdamaian di luar persidangan; menuntun para pihak dalam pembuktian; dan menjelaskan upaya hukum yang dapat ditempuh para pihak. Ada 2 jenis perkara yang tidak dapat diselesaikan dalam Small Claim Court yakni perkara yang penyelesaian sengketanya dilakukan melalui pengadilan khusus dan perkara sengketa hak atas tanah. Sistem ini mengenal dismissalprocess, yang mana dalam sidang pendahuluan hakim berwenang menilai dan menentukan apakah perkara tersebut masuk kriteria gugatan sederhana atau tidak. Apabila hakim berpendapat perkara bukanlah gugatan sederhana, maka dikeluarkan penetapan yang menyatakan pemeriksaan perkara tidak berlanjut.

Dengan berlakunya Peraturan Mahkamah Agung No. 4 Tahun 2019 yang menggantikan 
aturan sebelumnya No. 2 Tahun 2015 Tentang Gugatan Sederhana, cukup efektif untuk menyelesaikan sengketa bernilai gugatan kecil ( maksimal 500 juta) dengan waktu yang terjangkau yaitu 25 hari, namun mekanisme gugatan sederhana ( smallclaimscourt) ini belum spesifik diperuntukkan untuk menyelesaikan sengketa konsumen di pengadilan. Dengan penyelesaian melalui pengadilan yang mana smallclaimscourt ini menjembatani antara prosedur formal dan informal maka dalam hal prosedural serta eksekusi putusan akan lebih memaksa. Mengingat bahwa sengketa konsumen pada umumnya bernilai gugat kecil, maka hasil penelitian menunjukkan bahwa mekanisme gugatan sederhana sebagai salah satu alternatif penyelesaian sengketa konsumen yang lebih dapat memberikan kepastian hukum.

\section{PENUTUP}

Penyelesaian sengketa konsumen dapat diselesaikan baik secara litigasi maupun non litigasi. Pada perkembangannya dewasa ini terdapat berbagai lembaga penyelesaian sengketa konsumen selain Badan Penyelesaian Sengketa Konsumen (BPSK) sehingga dalam praktiknya terjadi pluralisme peraturan dan kelembagaan

Sebagaimana praktik di negara lain yang memberdayakan pengadilan sebagai lembaga penyelesaian sengketa konsumen melalui small claim sprosedures dan lembaga small claim scourt, maka konsep tersebut seyogyanya dapat diterapkan pula di Indonesia. Melalui Peraturan Mahkamah Agung No. 4 Tahun 2019 Tentang Gugatan Sederhana yang mengadopsi mekanisme Small Claims Court ditinjau sangat sesuai digunakan untuk menyelesaikan sengketa konsumen yang berkarakter gugat dengan nilai kecil.

\section{DAFTAR PUSTAKA}

Buku :

Az. Nasution, 2011, Hukum Perlindungan Konsumen Suatu Pengantar, Diadit Media.

Christopher J. Wheelan, 1990, Small Claims Courts - A Comparative Study, Oxford University Press, New York.
HarisFaulidiAsnawi, 2004, TransaksiBisnis ECommerce Perspektif Islam, MagistraInsania Press, Yogyakarta.

$\mathrm{H}$ i $\mathrm{km}$ a h a $\mathrm{n}$ t o J u w a n a, 2002,BungaRampaiHukumEkonomi Dan HukumInternasional, LenteraHati, Tangerang

Ross Craston, 2004, The Rational Study ofLaw:SocialResearchand Access To Justice, dalam Deborah L Rhode, Access To Justice, Oxford UniversityPress, Oxford, hlm 24

Tata Wijayanta dan Hery Firmansyah, 2011, Perbedaan Pendapat dalam Putusan Pengadilan, Pustaka Yustisia, Yogyakarta. Walner, 2008, Ralph Everybody's Guide to Small Claims Court, 12th Edition, United States: NOLO.

\section{Jurnal}

AgusSatory, 2015, Perjanjian Baku dan Perlindungan Konsumen dalam Transaksi Bisnis Sektor Jasa Keuangan: Penerapan dan Implementasinya di Indonesia", PADJADJARAN Jurnal Ilmu HukumVolume 2 Nomor 2 Tahun

Agus Swandono dan Deviana Yuanitasari, 2016, Jas a Ke uanganDala $\mathrm{mHukum}$ PerlindunganKonsumen, Jurnal Bina MuliaHukum, Fakultas Hukum Universitas Padjadjaran, Vol 1 No. 1.

Anita Afriana dan Efa Laela Fakhriah, 2019, $U n d e r s t a n d i n g t h e$ PluralityofConsumerDisputeResolution in Indonesia: A Comparative Study WithSingapore, Jurnal Yuridika, Fakultas Hukum Universitas Airlangga, Vol 34 No. 1, Januari 2019

ErmanRajagukguk," PerananHukumdalam Pembangunan Pada Era Globalisasi" JurnalHukumBisnis, No II Vol 6.

Rahmi Rimanda, 2019, Keberadaan Badan PenyelesaianSengketaKonsumen (Bpsk) Sebagai Lembaga Quasi Yudisial Di Indonesia, Jurnal Bina Mulia Hukum, Fakultas Hukum Universitas Padjadjaran, Vol IV No. 1, September 2019 
MENINJAU KEMBALI PENYELESAIAN SENGKETA KONSUMEN DI INDONESIA....(Anita Afriana; Sudaryat; Rai Mantili; Ema Rahmawati, 74-83)

\section{Sumber Lain}

Anita Afriana, etall, Konsep Penyelesaian Sengketa Konsumen ( Consumer Dispute) Yang , Berkepastian Hukum: Dalam Perspektif Pembaharuan Hukum Dalam Rangka Globalisasi, Laporan Akhir Penelitian Dasar Unggulan Perguruan Tinggi, Tahun 2018.

ErmanRajagukguk, PluralismeHukum di Indonesia, makalah disampaikan pada Kongres Internasionalke 15 tentang Pluralisme Hukum, FH UI, Depok, 26 Juni 2006.

\section{(Footnotes)}

${ }^{1}$ Tata Wijayanta dan HeryFirmansyah, 2011, Perbedaan Pendapat dalam Putusan Pengadilan, Pustaka Yustisia, Yogyakarta, hlm14.

${ }^{2}$ E. Sa efullah Wiradipradja., 2012 ,“ DampakNegatif Globalisasi Terhadap Persatuan Dan Kesatuan Bangsa Indonesia Dan Strategi Menghadapinya“ dalamAnAnChandrawulanetal, "Kompilasi Hukum Bisnis Dalam Rangka Purnabakti Prof. Dr. H. Man Sastrawidjaja. S.H., S.U., " CV. Keni, Bandung,hlm. 55.

${ }^{3} \mathrm{H} \mathrm{i} \mathrm{k} \mathrm{m} \mathrm{a} \mathrm{h} \mathrm{a} \mathrm{n} \mathrm{t} \mathrm{o} \mathrm{J} \mathrm{u} \mathrm{w} \mathrm{a} \mathrm{n} \mathrm{a,} 2002$, BungaRampaiHukumEkonomi Dan HukumInternasional, LenteraHati, Tangerang, hlm. 23.

${ }^{4}$ HarisFaulidiAsnawi, 2004, TransaksiBisnis ECommerce Perspektif Islam, MagistraInsania Press, Yogyakarta, hlm. 42

${ }^{6}$ Walner, 2008, Ralph Everybody's Guide to Small Claims Court, 12th Edition, United States: NOLO, hlm152. ${ }^{7}$ Rahmi Rimanda, 2019,

KeberadaanBadan Penyelesaian Sengketa Konsumen (Bpsk) Sebagai Lembaga Quasi Yudisial Di Indonesia, Jurnal Bina Mulia Hukum, Fakultas Hukum Universitas Padjadjaran, Vol IV No. 1, September 2019, hlm 26

${ }^{8}$ Ibid, hlm 31-32

${ }^{9}$ AgusSuwandono dan DevianaYuanitasari, 2016, Kedudukan Lembaga Alternatif Penyelesaian Sengketa Jasa Keuangan
Dalam Hukum Perlindungan Konsumen, Jurnal Bina Mulia Hukum, Fakultas Hukum Universitas Padjadjaran, Vol 1 No. 1, hlm14

${ }^{10}$ Anita Afriana dan Efa Laela Fakhriah, 2019, Understandingthe Pluralityof Consumer Dispute Resolution in Indonesia: A Comparative Study WithSingapore, Jurnal Yuridika, Fakultas Hukum Universitas Airlangga, Vol 34 No. 1, Januari 2019, hlm 12

${ }^{11}$ ErmanRajagukguk, PluralismeHukum di Indonesia, makalahdisampaikan pada Kongres Internasionalke 15 tentang Pluralisme Hukum, FH UI, Depok, 26 Juni 2006.

${ }^{12}$ Agus Satory, 2015, Perjanjian Baku dan P e rlindungan Kon sumen dalamTransaksiBisnisSektorJasaKeuangan: Penerapan dan Implementasinya di Indonesia“,PADJADJARAN Jurnal IlmuHukum Volume 2 Nomor 2 Tahun, hlm3.

${ }^{13}$ Anita Afriana, etall, Konsep Penyelesaian Sengketa Konsumen ( Consumer Dispute) Yang, Berkepastian Hukum: Dalam Perspektif Pembaharuan Hukum Dalam Rangka Globalisasi, Laporan Akhir Penelitian Dasar Unggulan Perguruan Tinggi, Tahun 2018, hlm 40

${ }^{14}$ ErmanRajagukguk," PerananHukumdalam Pembangunan Pada Era Globalisasi" JurnalHukumBisnis, No II Vol 6:114

${ }^{15}$ Christopher J. Wheelan, 1990, Small Claims Courts - A Comparative Study, Oxford University Press, New York, hlm 53.

${ }^{16}$ Ross Craston, 2004, The Rational Study ofLaw:SocialResearchand Access To Justice, dalam Deborah L Rhode, Access To Justice, Oxford UniversityPress, Oxford, hlm 24. 